\title{
ROZHLADY
}

\section{PROZODICKÉ A PRAGMATICKÉ VLASTNOSTI KONVERZAČNÝCH HEZITÁCIÍ V ANGLIČTINE}

\author{
ŠTEFAN BEŇUŠ
}

BEŇUŠ, Štefan: Prosodic and Pragmatic Characteristics of Conversational Fillers in English. Jazykovedný časopis, 2011, Vol. 62, No. 2, pp. 119 - 129. (Bratislava)

Conversation fillers are sounds like $u h$ or $u m$ that commonly occur in spontaneous conversational speech. When these sounds are noticed, they are commonly perceived negatively in that speakers are considered unprepared, nervous, or less confident. This paper reviews several recent studies dealing with linguistic, psycholinguistic, and neurolinguistic aspects of conversational fillers and suggests that, despite generally negative perception, conversational fillers play an important role in interpersonal spoken interactions and function positively in facilitating communication. For example, they signal intonational or syntactic structure, cue given vs. new entities in discourse, increase attention, improve retention of words following them in memory, or signal metacognitive states of the speaker to the listener. These functions bring potential of using conversational fillers in various applications that are based on interactive speech and voice processing. Further studies of fillers in languages like Slovak may improve our understanding of the complexities of human spoken interactions.

\section{1. ÚVOD}

Spontánna l'udská reč, najmä pri interaktívnej komunikácii, sa vyznačuje vel'kým počtom zvukov, ako $u h$ alebo $e h m$, ktoré sa najčastejšie vnímajú ako prejav váhania. V anglickej literatúre sa pre tieto zvuky používa termín filled pause, resp. čoraz častejšie conversational filler (napr. Clark - Fox Tree, 2002). V príspevku budem tieto zvuky označovat' ako hezitácie (podl'a angl. hesitation - váhanie). Frekvencia týchto zvukov sa $v$ rôznych štúdiách a typoch reči pohybovala od $2,5 \%$ všetkých slov v korpuse Switchboard pri telefónnych dialógoch medzi neznámymi l'ud'mi (Shriberg, 2001) alebo pri konverzačných hrách s laptopmi, pri ktorých sa hovoriaci nevidia (Beňuš 2009a) do 4,5\% v kontrolovaných interview zameraných na zistenie, či hovoriaci klame (Benus - Enos - Hirschberg - Shriberg, 2006). To znamená, že frekvencia týchto zvukov je porovnatel'ná s frekvenciou najbežnejších slov.

$\mathrm{V}$ tomto prehl'adovom príspevku predstavujem niekol'ko nedávnych štúdií rôznych lingvistických, psychologických a kognitívnych funkcií týchto zvukov, čím chcem ukázat', že napriek ich všeobecne negatívnemu vnímaniu majú tieto zvuky viacero pozitívnych vplyvov na rečovú komunikáciu a ich štúdium aj v jazykoch ako slovenčina má potenciál priniest' zaujímavé poznatky pri snahe o lepšie pochopenie komplexnosti medzil’udskej rečovej komunikácie. 


\section{BEŽNÝ POHLAD NA HEZITÁCIE}

Bežný pohl'ad na hezitácie a ich vnímanie $\mathrm{v}$ širokej verejnosti dost' negatívny. Vo všeobecnosti sa hezitácie považujú za „pomocné barličky“ hovoriaceho, ktoré však spomal'ujú porozumenie a celkovo zhoršujú jeho kvalitu pre počúvajúcich. V lepšom prípade si ich počúvajúci ani neuvedomujú, v horšom počúvajúci „trávia čas detekciou ich zbytočnosti“, a v extrémnych prípadoch pôsobia vyslovene rušivo. Tento pohlad platí nielen pre rečovú komunikáciu medzi l'ud'mi ale aj pri automatickom rozpoznávaní reči. Hezitácie sú $\mathrm{v}$ angličtine foneticky podobné mnohým slovám (napr. neurčitý člen) alebo ich začiatkom a ich správna detekcia a odstránenie zo signálu pred tým, ako sa začne s automatickým rozpoznávaním reči prináša zlepšenia $\mathrm{v}$ kvalite rozpoznávania.

Hezitácie taktiež pôsobia negatívne na vnímanie osobnosti hovoriaceho. Nicolas Christenfeld vo svojej štúdii (1995) napríklad ukázal, že hovoriaci s hezitáciami pôsobia na počúvajúcich nervózne, nepripraveno, bez sebadôvery a nezaujímavo. Tento negatívny pohl'ad bol potvrdený v citovanej štúdii aj kvantitatívne. Autori vybrali niekol'ko nahratých monológov $\mathrm{s}$ hezitáciami a vytvorili $\mathrm{z}$ tohto materiálu tri skupiny: pôvodný monológ $\mathrm{s}$ hezitáciami (na obrázku 1 označené prázdnymi krúžkami), všetky hezitácie nahradené tichom v rovnakej dížke ako hezitácia (plné štvorce) a hezitácie úplne odstránené zo signálu (prázdne trojuholníky). Tieto monológy potom hodnotili l'udia na škále „elokvencie“, čiže kvality hovoreného prejavu (y-ová os) v troch skupinách: v prvej požiadali l'udí, aby sa sústredili na obsah prejavu, v druhej na štýl (teda na formu) a tretia bola kontrolná skupina. Tieto tri skupiny sú zobrazené na x-ovej osi obrázku 1.

Z obrázku je jasné, že reč bez hezitácií je považovaná za najlepšiu, ale tiež to, že pri sústredení sa na obsah pôsobia hezitácie menej rušivo ako intervaly ticha, ale pri sústredení sa na štýl je tento vzt’ah obrátený.

K negatívnemu obrazu hezitácií prispieva aj to, že pri kurzoch hovoreného prejavu, ako napríklad pri praktickej rétorike, sa aktívne pracuje na ich odstránení alebo aspoň na ich minimalizovaní. Množstvo manuálov v tejto oblasti upozorňuje na hezitácie ako na niečo, čoho by si hovoriaci mal byt' vedomý a čo by mal mat' pod vlastnou kontrolou (napr. Lucas, 2004). N. Christenfeld cituje štúdiu Jamesa Deesea, ktorý hovorí:

„Speech without filled pauses gives a sense of directness and strength, and, what is more, of the speaker's superiority“ (Deese, 1984, s. 100, cit. podl'a N. Christenfeld, 1995, s. 172). ${ }^{1}$ Navyše hezitácie sa hodnotia ako negatívny faktor, ktorý ovplyvňuje plynulost' pri produkcii cudzích jazykov.

Okrem iného sa zistilo, že absencia nejazykových modalít zvyšuje frekvenciu hezitácií, z čoho možno vyvodit', že hezitácie sú neprirodzeným jazykovým prejavom. Napríklad pri porovnávaní dialógov s vizuálnym kontaktom hovoriacich a bez-

${ }^{1}$ Rečový prejav bez hezitácií vyvoláva dojem úprimnosti a presvedčivosti a navyše aj dominantnosti hovoriaceho. 


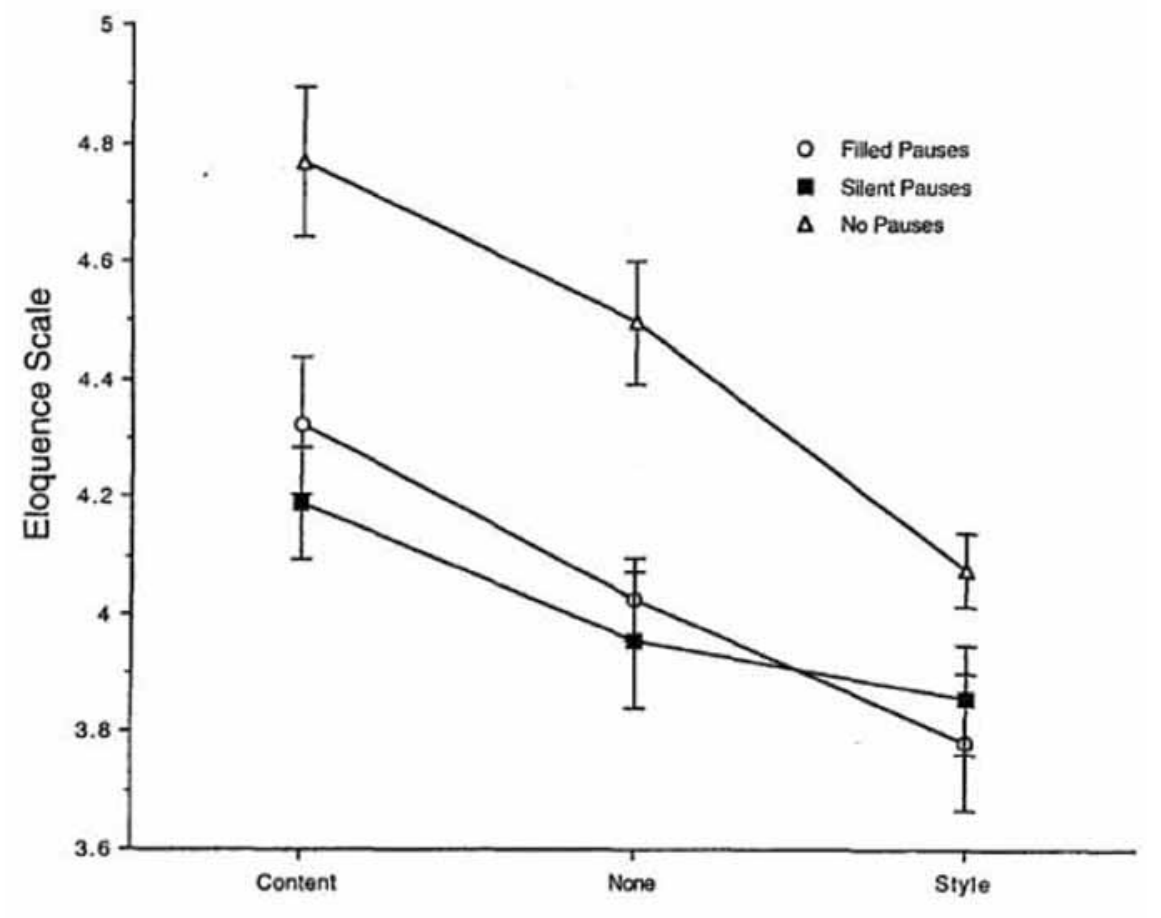

Focus

Obr. 1: Hodnotenie hezitácií v monológoch, štandardné odchýlky pre každú skupinu sú naznačené zvislými úsečkami. (Prevzaté z Christenfeld, 1995, s.182.)

neho, ako napríklad pri telefonovaní, sa ukázalo, že telefonovanie má väčšiu frekvenciu hezitácií ako rozhovory, pri ktorých sa hovoriaci navzájom vidia (Oviatt, 1995). Absencia možnosti gestikulácie, ktorá je prirodzeným prejavom pri rečovej komunikácii, takisto zvyšuje frekvenciu hezitácií. Michael Erard (2007) napríklad uvádza, že ked' musia mat' hovoriaci ruky vo vreckách, alebo ked' si na nich sedia, používajú vtedy viac hezitácií, ako ked' majú ruky vol’né. Ked’že sa zdá, že frekvencia hezitácí́ sa zvyšuje úmerne tomu, do akej miery klesá prirodzenost' konverzácie, používanie hezitácií môže byt' považované za neprirodzený element rečovej komunikácie.

V krátkosti, hezitácie sú vnímané ako rušivý prvok pri rozhovoroch, čo je podporené viacerými vedeckými štúdiami. V d’alšej časti tejto práce však predstavím niektoré poznatky a novšie štúdie podporujúce názor, že hezitácie sú jazykovým prostriedkom, ktorý vel'mi aktívne vstupuje do komunikácie, má potenciál pozitívne vplývat' na komunikačný proces, a štúdium ich produkcie a percepcie môže priniest' 
nové poznatky v rôznych odvetviach, ktoré sa venujú bádaniu l’udského správania, ako napríklad v lingvistike, psychológii (klinickej aj experimentálnej), kognitívnych vedách, ako aj pri aplikáciách, ktoré využívajú komunikáciu, či už medzi l'ud’mi alebo aj v automatických dialógových systémoch.

\section{POZITÍVNE FUNKCIE HEZITÁCIÍ V REČOVEJ KOMUNIKÁCII}

\subsection{Lingvistické funkcie}

V oblasti lingvistických funkcií umiestnenie a charakteristika hezitácií v monológoch signalizuje intonačnú aj diskurznú štruktúru. Marc Swerts (1998) ukázal, že dôležité intonačné a diskurzné hranice sú často nasledované hezitáciami. Čiže ked' hovoriaci prechádza $\mathrm{z}$ jednej témy na druhú, alebo ked' v rámci monológu začína nový diskurzný segment, je pravdepodobné, že takáto štruktúrna hranica bude okrem iných prozodických, syntaktických a lexikálnych aspektov označená aj hezitáciou. To umožňuje počúvajúcemu efektívnejšie predpokladat', kedy napríklad nastáva zmena témy a vo všeobecnosti lepšie rozpoznávat’ diskurznú a intonačnú štruktúru prichádzajúcej reči. Swertsova štúdia analyzovala monológy v holandčine a tiež ukázala, že na hraniciach štruktúrnych celkov, či už intonačných alebo diskurzných, sa častejšie vyskytovala hezitácia končiaca na nazálny zvuk, bežne prepisovaná ako um, ako hezitácia bez tohto nazálneho ukončenia prepisovaná ako $u h$. Hezitácie na takýchto hraniciach mali takisto vyššiu priemernú základnú frekvenciu a aj dlhšie trvanie ako hezitácie mimo hraníc.

V oblasti syntaxe sa zistilo, že hezitácie ovplyvňujú štruktúrnu analýzu v reálnom čase (Ferreira - Lau - Bailey, 2004). Na ilustráciu môžeme uviest' slovenskú vetu „Ked' muž pílil strom ...“, pri ktorej väčšina l’udí analyzuje slovo strom ako predmet prísudku pílil. Ak sa však d’alej pokračuje „,... sa zaknísal“, táto pôvodná analýza sa ukáže ako nesprávna a je potrebné analyzovat' slovo strom nie ako predmet v prvej časti súvetia, ale ako podmet v druhej časti. ${ }^{2} \mathrm{Ak}$ sa hezitácia vyskytne za slovom strom, predlžuje tým interval, počas ktorého je syntaktický analyzátor v „zlej“ analýze. Tým pádom aj predlžuje čas, ktorý je potrebný na re-analýzu vety, ked' zistíme jej pokračovanie.

Hezitácie však pomáhajú aj pri analýze nejednoznačných viet, čím opät pôsobia pozitívne na komunikáciu. V našej ilustračnej vete „Ked’ muž pílil strom sa zaknisal", môžeme povedat', že slovo strom má potenciálne nejednoznačnú syntaktickú funkciu v čase jeho vyslovenia. Ak sa hezitácia vyskytne pred ním, teda medzi slovami pílil a strom, upozorňuje na prítomnost' hranice medzi dvomi syntaktickými celkami (podobne ako pri hraniciach medzi intonačnými a diskurznými celkami, o ktorých sme sa zmieňovali vyššie), a napomáha tak „správnej“ syntaktickej analý-

${ }^{2}$ Samozrejme, pri písanom texte je takáto nejednoznačnosť v tomto prípade nemožná, lebo v plnej vete by sa vyskytovala za slovom pílil čiarka. Pri takýchto experimentoch však ide bud' o porozumenie hovorenej reči, alebo o online porozumenie, kde sa na obrazovke ukazuje vždy iba jedno slovo. Tento typ viet, pri ktorých je potrebná re-analýza, či už syntaktická, sémantická alebo iná, je známy pod anglickým názvom „garden path sentences“ (GPS). 
ze vety, a teda efektívnejšiemu porozumeniu, v reálnom čase. Navyše automatický analyzátor syntaktickej štruktúry viet má lepšiu úspešnost' vtedy, ak sa hezitácie ponechajú $\mathrm{v}$ texte, ktorý predstavuje vstup do analyzátora, ako ked' sa hezitácie najprv odstránia (Charniak - Johnson, 2001).

V pragmatickej oblasti majú hezitácie tendenciu signalizovat' slová a koncepty, ktoré ešte neboli spomenuté $\mathrm{v}$ doterajšom priebehu dialógu (Barr, 2001; Arnold Fagnano - Tanenhaus, 2003; Arnold - Altmann - Fagnano - Tanenhaus, 2004, a iné). V štúdiách Arnoldovej a jej spolupracovníkov sa napríklad skúmali pohyby očí pri komunikatívnej úlohe, ktorá vyžadovala presuny myšou medzi viacerými obrázkami na obrazovke počítača. Jedným zo zistení bolo, že pri inštrukciách, ktoré obsahovali hezitácie, ako na príklad: „teraz sa presuň na uh...", sa účastníci systematicky pozerali na tie predmety na obrazovke, ktoré ešte neboli v doterajšom trvaní hry spomenuté, čo zodpovedalo tomu, že l'udia majú tendenciu použit' hezitáciu pri hovorení o predmetoch a činnostiach, ktoré sú v diskurze nové. Opät' teda použitie hezitácií napomáha pri efektívnosti a bezproblémovosti komunikácie.

Preberanie slova a striedanie hovoriacich $\mathrm{v}$ dialógoch tiež patrí medzi dôležité lingvistické roviny, pri ktorých sa skúma najmä vzt’ah medzi formou výpovede (prozodickou a syntaktickou) a jej pragmatickou funkciou $\mathrm{v}$ interakcii hovoriacich. Ťažisko výskumu je $\mathrm{v}$ robustnom identifikovaní tých miest $\mathrm{v}$ dialógu, ktoré môžu slúžit' ako potenciálne miesto na zmenu hovoriacich (Transition Relevance Place, TRP), ich prozodické a syntaktické signalizovanie a miera stochasticity, teda pravdepodobnosti, zmeny hovoriacich na takýchto miestach. Hezitácie vel'mi významne vstupujú do procesu striedania sa hovoriacich tým, že signalizujú úmysel hovoriaceho nebyt' prerušený a udržat' si slovo aj napriek tomu, že syntakticky alebo prozodicky nastalo TRP, teda miesto vhodné na to, aby si komunikačný partner zobral slovo. Táto hlavná funkcia hezitácie môže byt' doplnená menej bežnými funkciami, pri ktorých hezitácia signalizuje, že hovoriaci už nechce pokračovat' d’alším prehovorom, alebo sa mu ho nedarí dobre naplánovat', a teda ponúka svojho partnera, aby prebral slovo, alebo je to signál toho, že hovoriaci má úmysel si slovo zobrat' (Stenström, 1990).

\subsection{Paralingvistické, psycholingvistické a neurolingvistické funkcie}

V tejto rovine môžu hezitácie napríklad naznačovat' kognitívny zdroj váhania. Herbert Clark a Jean Fox Treeová (2002) zistili, že prípady typu um v angličtine väššinou signalizujú hlbšie problémy pri plánovaní prehovoru, zatial' čo prípady typu $u h$ väčšinou signalizujú problémy pri hl’adaní správneho slova alebo slovného spojenia. Na základe tohto zistenia potom argumentovali, že um a $u h$ sa dajú považovat' za rozdielne slová aj napriek tomu, že nemajú lexikálny význam, lebo sú navzájom kontrastné svojím paralingvistickým významom.

Tento návrh otvára zaujímavé pole pre interkultúrny a interjazykový výskum, či sa podobné rozdiely dajú pozorovat' aj v jazykoch, ktoré majú len jednu hlavnú formu hezitácie, ako je to napríklad v slovenčine, alebo v jazykoch, ktoré ich majú viac, 
ako napríklad v japončine. V tejto súvislosti je potrebné spomenút' nedávnu štúdiu Esther de Leeuwovej (2007), kde sa argumentovalo, že rozdiel medzi um a $u$ h, o ktorom hovorili Clark a Fox Treeová, je platný pre americkú angličtinu, ale nemusí platit’ pre angličtinu britskú.

V neposlednom rade hezitácie zefektívňujú aj proces výmeny informácií medzi hovoriacimi tým, že pri váhaní naznačujú dĺžku intervalu ticha od konca predchádzajúceho prehovoru po začiatok d'alšieho. Napríklad Štefan Beňuš a kol. (Benus - Enos - Hirschberg - Shriberg, 2006) zistili, že čím dlhšia je hezitácia, tým je dlhší interval ticha pred ňou aj za ňou. Navyše, podporená bola aj myšlienka kontrastu medzi um a $u h$ v angličtine tým, že intervaly ticha v okolí um sú dlhšie ako v okolí $u h$.

Je pravdepodobné, že hezitácie majú efekt zvýšenia pozornosti počúvajúceho. Tomu zodpovedajú aj výsledky zistené v štúdii Jean Fox Treeovej (Fox Tree, 2001), v ktorej výskyt hezitácie $u h$ urýchl'oval a celkovo ul'ahčoval percepciu jazykového materiálu za ňou. Túto pozitívnu funkciu hezitácie podporujú aj výsledky experimentov merajúcich mieru zapamätania slov a mozgovej aktivity v závislosti od prítomnosti hezitácie (Corley -MacGregor - Donaldson, 2007; Collard - Corley - MacGregor - Donaldson, 2009). Hezitácie napríklad zlepšujú zapamätanie si slov a konceptov, ktoré sa nachádzajú bezprostredne za nimi (Corley - Stewart, 2008). V neurolingvistickej štúdii merali Corley a kolegovia (2007) hodnoty mozgovej aktivity pri slovných spojeniach, kde hlavnou kontrolovanou premennou bol výskyt alebo absencia hezitácie. Sústredili sa na takzvaný N400, čo je označenie mozgovej aktivity (event related potential, ERP), meratel'ný technológiou elektroencefalogramu v strednej temennej oblasti zhruba 400 milisekúnd od počutia signálu. Táto aktivita je závislá od miery pravdepodobnosti slovného spojenia tak, že nepravdepodobné spojenie slov zvyšuje mozgovú aktivitu, čo sa prejavuje zvýšenou mierou N400. Čiže ak je spojenie dvoch slov nepravdepodobné, N400 v ERP experimentoch je signifikantne väčší ako pri pravdepodobnom spojení. Corley s kolektívom zistili, že výskyt hezitácie pri nepravdepodobnom spojení výrazne znižuje tento efekt, čiže ul'ahčuje spracovanie a vyhodnotenie nepravdepodobného slovného spojenia.

Hezitácie sa tiež aktívne zapájajú do komunikačného procesu a priaznivo ovplyvňujú úspešné výsledky tohto procesu. Napríklad hezitácie upozorn̆ujú na prichádzajúcu opravu slova alebo myšlienky a ul'ahčujú tak plnenie interaktívnych úloh (Brennan - Schober, 2001). Tým, že označujú miesta možných opráv, upozorňujú aj na miesta s nesprávnou alebo neúplnou syntaktickou štruktúrou vety alebo morfologickou štruktúrou slova. Vd'aka tomu môžu hezitácie pomáhat' aj pri osvojovaní si jazyka tým, že upozorňujú na gramaticky nesprávne alebo neúplné štruktúry (napr. Soderstrom - Morgan, 2007).

\subsection{Metakognitívne a sociolingvistické funkcie}

Hezitácie plnia aj rôzne metakognitívne funkcie. V známej štúdii Susan E. Brennanovej a Mauricea Williamsa (1995) prehrávali l’ud'om krátke dialógy 
vo forme otázky a odpovede. Napríklad otázka bola: „Čo je hlavným mestom Kana$d y$ ?"“ a odpoved' mohla byt': „Ottawa“, alebo ,uh Ottawa“, alebo interval ticha nasledovaný odpoved'ou, alebo len samotná hezitácia. Autori zistili, že ak je odpoved' na otázku spojená s hezitáciou, l'udia predpokladajú, že hovoriaci si je menej istý odpoved'ou, ale aj to, že je viac pravdepodobné, že odpoved' vedel, aj ked' ju v konečnom dôsledku nevyslovil. Hezitácie teda napomáhajú prisudzovaniu duševného a rozumového rozpoloženia medzi hovoriacimi.

N. Christenfeld (1995) argumentoval, že produkcia hezitácií najviac koreluje s rozmýšl’aním a že frekvencia hezitácií rastie úmerne tomu, čím abstraktnejšie a zložitejšie sú témy prehovorov. Vel'mi zaujímavým zistením bolo, že korelácia frekvencie hezitácií s nervozitou hovoriaceho, jeho skúsenost’ami s témou, poznaním komunikačných partnerov, alebo časom prípravy je vel'mi slabá. Tento fakt je v priamom rozpore $\mathrm{s}$ bežným vnímaním hezitácií, ktoré sa nachádzali v tej istej štúdii a spomenuli sme ich vyššie, že hezitácie hovoriaceho l'udia vnímajú ako nepripravenost', nervozitu alebo nedostatočné poznanie problematiky alebo iných účastníkov komunikácie. Táto štúdia teda priamo poukazuje na rozpor medzi faktormi ovplyvňujúcimi frekvenciu hezitácií pri produkcii reči a faktormi, ktoré sú vnímané ako dôležité pre percepciu.

N. Christenfeld tiež ukázal, že vnímanie hezitácií je relatívne nespol’ahlivé. V monológoch, v ktorých boli hezitácie odstránené alebo nahradené tichom, si počúvajúci aj tak mysleli, že tam sú.

V nasledujúcej štúdii N. Christenfeld spolu s Beth Creagerovou presvedčivo argumentovali, že výskyt hezitácií pozitívne koreluje so stupňom pozornosti, ktorú hovoriaci venuje svojej reči (Christenfeld - Creager, 1996). Jedným z hlavných argumentov bolo zistenie, že alkohol, ktorý st’ažuje produkciu reči, znižuje aj pozornost' venovanú vlastnej reči. Pri porovnaní reči l’udí, ktorí požili alebo nepožili alkohol, sa zistilo, že alkohol dramaticky znižuje výskyt hezitácií a frekvencia hezitácií je negatívne závislá od miery požitia alkoholu.

Poslednou metakognitívnou funkciou, ktorú spomeniem, je to, že hezitácie sa vo všeobecnosti považujú za prejav klamania (napr. Fox Tree, 2002, Benus - Enos - Hirschberg - Shriberg, 2006). Súvisí to s tým, že prerozprávanie príbehu alebo situácie, ktoré sa stali, verne nie je kognitívne také náročné, ako naplánovanie nového príbehu, ktorý zapadá do kontextu a hovoriaci nám „nestráca tvár“ (Oomen - Postma, 2001). Ale vo viacerých štúdiách, ktoré analyzovali reč pri klamaní - od simulovaných interview až po nahrávky usvedčených vrahov - bolo používanie hezitácií častejšie pri pravdivých prehovoroch ako pri klamlivých (Benus - Enos - Hirschberg - Shriberg, 2006, Arciuli - Mallard - Villar, 2010, Villar - Arciuli - Mallard, 2012). Toto zistenie pravdepodobne súvisí s tým, že ak hovoriaci má čas svoje klamstvo naplánovat', je potom pri jeho produkcii plynulejší, a tak používa menej hezitácií ako pri prehovoroch, ktoré sú pravdivé.

Spomeniem aj jednu zo sociolingvistických funkcií hezitácií, ktorá poukazuje na rozdiel medzi pohlaviami. Muži používajú hezitácie častejšie ako ženy, čo bolo 
preukázané v rôznych korpusoch a štýloch reči (Shriberg, 2001; Bortfeld - Leon Bloom - Schober - Brennan, 2001, Benus - Enos - Hirschberg - Shriberg, 2006). Z toho, čo som uviedol vyššie, sa možno domnievat', že muži sa hezitáciami snažia o udržanie slova a tým o väčšiu dominanciu v dialógoch. Alebo je možné, že muži venujú väčšiu pozornost' svojmu rečovému prejavu ako ženy, čo má za následok tento rozdiel vo frekvencii hezitácií. Sú to však len domnienky a hlbšie pochopenie rozdielov medzi pohlaviami a inými sociolingvistickými aspektmi používania hezitácií si vyžaduje systematické skúmanie v tejto oblasti.

Na záver sa dotknem aj štúdie, ktorá poukazuje na spoločensko-politickú funkciu hezitácií. Geoffrey Beattie (1982) porovnával interview kandidátov na post ministerského predsedu pred vol'bami vo Vel'kej Británii Margaret Thatcherovej a Jamesa Callahana. Vo všeobecnosti bola Thatcherová považovaná za dominantnú političku s prezývkou „železná lady“ a Callahan za vel’mi ústretového a nekonfliktného politika s prezývkou „usmievavý Jim (Sunny Jim)“. Toto vnímanie však nekorešpondovalo s verbálnym správaním kandidátov počas rozhovorov: M. Thatcherová, bola často prerušovaná moderátorom a sama prerušovala minimálne, kým J. Callahan nebol skoro vôbec prerušovaný a sám prerušoval moderátora vel'mi často. Vznikol teda paradox, že $\mathrm{M}$. Thatcherová je vnímaná ako dominantnejšia politička než J. Callahan, aj ked' štýl ich rozhovorov by mal svedčit' o opaku. Jedno z vysvetlení, ktoré G. Beattie ponúka, je absencia hezitácií u M. Thatcherovej ako signálu, že chce pokračovat' a nebyt' prerušená. $\mathrm{V}$ zhruba polhodinovom rozhovore mala $\mathrm{M}$. Thatcherová iba 4 hezitácie a naproti tomu J. Callahan ich mal v interview s rovnakou dížkou 22. G. Beattie sa domnieva, že poradci Thatcherovej odporučili vyvarovat'sa hezitácií, čo však malo taký efekt, že moderátor nevedel, kedy chce M. Thatcherová ešte pokračovat' a udržat' si slovo a kedy už nie a tak ju nevyhnutne musel prerušovat'. ${ }^{3}$ Ked'že M. Thatcherová si slovo nechcela nechat' zobrat', vnikali relatívne dlhé intervaly so simultánnou rečou oboch účastníkov, pri ktorých pôsobila M. Thatcherová dominantne. Opät' teda vhodné používanie hezitácií môže prispiet' k pozitívnemu obrazu politika medzi verejnost'ou a ich umelé potieranie môže priniest' negatívny efekt.

\subsection{Potenciál hezitácií $\mathrm{v}$ aplikáciách}

Po diskusii o mieste hezitácií pri rôznych lingvistických a nelingvistických funkciách jazyka spomeniem ešte dva príklady využitia hezitácií v aplikáciách, ktoré využívajú rečovú komunikáciu. Prvým je zistenie, že vhodné použitie a načasovanie hezitácií robota pri komunikácii s l'ud'mi signifikantne zlepšuje dojem, ktorý l’udia z tejto interakcie majú (Shiwa - Kanda - Imai - Ishiguro - Hagita, 2007). Aj napriek neustále sa zvyšujúcej produktivite počítačových a informačných systémov potrebuje robot s komunikatívnymi funkciami určitý čas na spracovanie reči, ktorú k nemu

${ }^{3}$ Thatcherová mala tiež vel’mi pomalé tempo reči v porovnaní s Callahenom, čo tiež prispieva $\mathrm{k}$ častejšiemu prerušovaniu moderátorom. 
človek vysiela, na výber správnej odpovede a na jej syntézu do akustického signálu. Ak robot tieto nevyhnutné intervaly vyplnil hezitáciami, dojem, ktorý mali l'udia z komunikácie s takýmto robotom, bol lepší, ako ked’ intervaly potrebné na spracovávanie reči boli vyplnené tichom.

Druhým príkladom je užitočnost’ hezitácií pri aplikáciách automatických tútorov, napríklad v aplikáciách ako ITSPOKE (Litman - Silliman, 2004). V týchto aplikáciách človek komunikuje s automatickým systémom, kde ciel’om je, aby si človek osvojil určité znalosti a zručnosti z rôznych oblastí školskej náplne. Automatický tútor kladie otázky, na ktoré študent odpovedá a vysoká frekvencia hezitácí je jedným $\mathrm{z}$ faktorov vedúcich systém $\mathrm{k}$ tomu, že študent aj napriek správnej odpovedi možno len háda, alebo si nie je dostatočne istý. Pri dosiahnutí určitej hranice potom môže systém vyhodnotit' určitý učebný celok ako nedostatočne osvojený a pristúpit' potom $\mathrm{k}$ doplňujúcim cvičeniam na utvrdenie si učiva.

\section{ZÁVER}

V tejto práci som chcel ukázat', že aj napriek tomu, že hezitácie sa vo všeobecnej populácii vnímajú ako negatívny prvok komunikácie, predstavujú bohatý zdroj informácií na mnohých rovinách produkcie a percepcie reči, čo môže pozitívne ovplyvňovat rečovú interakciu a aj aplikácie s ňou spojené. Hezitácie jednoznačne patria do lingvistického systému, pretože predstavujú systematickú a vnútornú vedomost' o vzt’ahu medzi zvukom a významom a hlbšie pochopenie systému, ktorý predstavujú, pomôže lepšie pochopit' interakciu kognitívneho jazykového systému $\mathrm{v}$ rôznych rovinách komunikácie.

Na záver si dovolím zamysliet' sa nad výsledkami známej štúdie, ktorá porovnávala frekvenciu hezitácií $\mathrm{v}$ prednáškach $\mathrm{z}$ humanitných, prírodných a spoločenských vied (Schachter - Christenfeld - Ravina - Bilous, 1991, 1994). Prednášky $\mathrm{z}$ humanitných vied obsahovali hezitácií najviac, a v prednáškach z prírodných vied ich bolo najmenej. Výsledky tejto prípadovej štúdie na 41 prednáškach na Columbia University sú podporené aj kvantitatívnou analýzou v Michigan Corpus of Academic Spoken English (Erard, 2007). Vel'mi zaujímavým zistením však bolo, že ked' tí istí prednášajúci rozprávali na všeobecné témy v rozhovore, nie na prednáške, frekvencie hezitácí sa medzi tromi akademickými disciplínami signifikantne nelíšili. Autori argumentovali, že $\mathrm{v}$ prednáškach aj textoch $\mathrm{z}$ prírodných vied sa vyskytuje menej termínov, teda menej možností na výber, a tým menší potenciál na hezitácie.

V súvislosti s týmito zisteniami by som rád uviedol tri krátke úvahy. Prvou je možnost', že hezitácie, ktoré sa používajú na prednáškach v humanitných vedách, môžu byt' sčasti zodpovedné za horší obraz humanitných vied v spoločnosti. Ked’že vieme, že hezitácie sa vnímajú vo všeobecnosti negatívne, a prednášajúci v humanitných vedách ich používajú $\mathrm{v}$ priemere najviac, negatívne vnímanie humanitných vied môže byt' čiastočne spôsobené aj hezitáciami. V tejto práci som sa však snažil ukázat', že všeobecne negatívne vnímanie hezitácií nemusí byt' založené na reálnych 
základoch. Druhou myšlienkou je, že hezitácie sa môžu vnímat' aj ako znak kreativity a plurality možností v humanitných vedách, čo ich kladie do protipólu určitej jednoznačnosti a presnosti prírodných vied. Z môjho pohl'adu sú pri vedeckom skúmaní potrebné oba póly (Beňuš, 2009b). A poslednou myšlienkou je, že spoločenské normy humanitných disciplín možno ,vyžadujú“ obraz zmýšl’avého prednášatel'a, ktorým si vedci zaoberajúci sa humanitnými vedami sčasti budujú vlastnú identitu a príslušnost' k tejto sociálnej skupine, a tým sa súčasne aj podiel'ajú na vytváraní tejto normy.

\section{Bibliografia}

ARCIULI, Joanne - MALLARD, David - VILLAR, Gina: “Um, I can tell you're lying”: Linguistic markers of deception versus truth-telling in speech. In: Applied Psycholinguistics 2010, roč. 31, s. $397-411$.

ARNOLD, Jennifer E. - ALTMANN, Rebecca - FAGNANO, Maria - TANENHAUS, Michael K.: The Old and Thee, uh, New. In: Psychological Science, 2004, roč. 15., č. 9, s. 578 - 582.

ARNOLD, Jennifer E. - FAGNANO, Maria - TANENHAUS, Michael K.: Disfluencies signal theee, um, new information. In: Journal of Psycholinguistic Research, 2003, roč. 32, č.1, s. 25 - 36.

BARR, Dale: Paralinguistic Correlates of Discourse Structure. Poster presented at the 43rd annual meeting of the Psychonomic Society, Orlando, USA, 2001.

BEATTIE, Geoffrey: Turn-taking and interruption in political interviews: Margaret Thatcher and Jim Callaghan compared and contrasted. In: Semiotica, 1982, roč. 39, č. 1/2, s. 93 - 114.

BEŇUŠ, Štefan: Turn-taking strategies in cooperative task dialogues. In: Discourse and Interaction, 2009a roč. 2, č. 1, s. $19-32$.

BEŇUŠ, Štefan: Building interfaces between the humanities and cognitive sciences: The case of human speech. In: Arts and Humanities in Higher Education, 2009b, roč. 9, s. 353 - 374.

BENUS, Stefan - ENOS, Frank - HIRSCHBERG, Julia - SHRIBERG, Elizabeth: Pauses and deceptive speech. In: Proceedings of $3^{\text {rd }}$ International Conference on Speech Prosody, Dresden, 2006.

BRENNAN, Susan E. - WILLIAMS, Maurice: The feeling of another's knowing: Prosody and filled pauses as cues to listeners about the metacognitive states of speakers. In: Journal of Memory and Language, 1995, roč. 34, s. $383-398$.

BRENNAN, Susan E. - SCHOBER, Michael: How listeners compensate for disfluencies in spontaneous speech. Journal of Memory and Language, 2001, roč. 44, s. $274-296$.

BORTFELD, Heather - LEON, Silvia - BLOOM, Jonathan - SCHOBER, Michael - BRENNAN, Susan: Disfluency rates in conversation: effects of age, relationship, topic, role, and gender. Language and Speech, 2001, roč. 44, č. 2, s. $123-147$.

CHARNIAK, Eugene - JOHNSON, Mark: Edit Detection and Parsing for Transcribed Speech. In: Proceedings of the 2nd Meeting of the North American Chapter of the Association for Computational Linguistics (NAACL), 2001.

CHRISTENFELD, Nicolas: Does it hurt to say um? In: Journal of Nonverbal Behavior, 1995, roč. 19, s. $171-186$.

CHRISTENFELD, Nicolas - CREAGER, Beth: Anxiety, alcohol, aphasia and ums. In: Journal of Personality and Social Psychology, 1996, roč. 70, s. $451-460$.

CLARK, Herbert H. - FOX TREE, Jean: Using uh and um in spontaneous speech. In: Cognition, 2002 , roč. 84 , s. $73-111$.

COLLARD, Philip - CORLEY, Martin - MACGREGOR, Lucy - DONALDSON, David: Attention orienting effects of hesitations in speech: Evidence from ERPs. In: Language and Cognitive Processes, 2009 , roč. 25 , s. $706-727$. 
CORLEY, Martin - STEWART, Oliver: Hesitation disfluencies in spontaneous speech: The meaning of um. In: Language and Linguistics Compass, 2008, roč. 4, s. $589-602$.

CORLEY, Martin - MACGREGOR, Lucy - DONALDSON, David: It's the way that you, er, say it: Hesitations in speech affect language comprehension. In: Cognition, 2007, roč. 105, s. 658 - 668 .

ENOS, Frank - BENUS, Stefan - CAUTIN, Robin L. - GRACIARENA, Martin - HIRSCHBERG, Julia, SHRIBERG, Elizabeth: Personality factors in human deception detection: Comparing human to machine performance. In: Proceedings of Interspeech, 2006, pp. $813-816$.

ERARD, Michael: Um: Slips, stumbles and verbal blunders and what they mean. New York: Pantheon 2007. 287 s.

FERREIRA, Fernanda - LAU, Ellen F. - BAILEY, Karl G. D.: Disfluencies, language comprehension, and Tree Adjoining Grammars. In: Cognitive Science, 2004, roč. 28, č. 5, s. 721 - 749.

FOX TREE, Jean: Interpreting Pauses and Ums at Turn Exchanges. In: Discourse Processes, 2002, roč. 34 , č. 1 , s. $37-55$.

FOX TREE, Jean: Listeners' uses of um and uh in speech comprehension. In: Memory and Cognition, 2001, roč. 29 , s. $320-326$.

JACOBSON, Roman: Closing Statements: Linguistics and Poetics. In: Style in language, Ed. Th. A. Sebeok, Cambridge MA: MIT Press 1960, s. $350-377$.

LEEUW, Esther, de: Hesitation markers in English, German, and Dutch. In: Journal of Germanic Linguistics, 2007, roč. 19, č. 2, s. $85-114$.

LITMAN, Diane - SILLIMAN, Scott: ITSPOKE: An Intelligent Tutoring Spoken Dialogue System. In: Proceedings of the Human Language Technology Conference: 4th Meeting of the North American Chapter of the Association for Computational Linguistics (HLT/NAACL), 2004.

LUCAS, Stephen: The art of public speaking. 8. vyd. McGraw-Hill Companies 2004.

OOMEN, Claudy C. E. - POSTMA, Albert: Effects of time pressure on mechanisms of speech production and self-monitoring. In: Journal of Psycholinguistic Research, 2001, roč. 30, s. 163 - 184.

SCHACHTER, Stanley - CHRISTENFELD, Nicolas - RAVINA, Bernard - BILOUS, Frances: Speech disfluency and the structure of knowledge. In: Journal of Personality and Social Psychology, 1991 , roč. 60 , s. $362-267$.

SCHACHTER, Stanley - RAUSCHER, Frances - CHRISTENFELD, Nicolas - TYSON CRONE, Kimberley: The vocabularies of academia. In: Psychological Science, 1994, roč. 5, s. $37-41$.

SHRIBERG, Elizabeth: To "Errrr" is Human: Ecology and Acoustics of Speech Disfluencies. In: Journal of International Phonetic Association, 2001, roč. 31, č. 1, s. 153 - 169.

SHRIBERG, Elizabeth - LICKLEY, Robin: Intonation of clause-internal filled pauses. In: Phonetica, 1993, roč. 50, s. $172-179$.

SHIWA, Toshiyuki - KANDA, Takayuki - IMAI, Michita - ISHIGURO, Hiroshi - HAGITA, Norihiro: How quickly should communication robots respond? In: Proceedings of the 3rd ACM/IEEE international conference on Human robot interaction, 2008, s. $153-160$.

SODERSTROM, Melanie - MORGAN, James: Twenty-two-month-olds discriminate fluent from disfluent adult-directed speech. In: Developmental Science, 2007, roč. 10, s. 641 - 653.

STENSTRÖM, Anna-Brita: Pauses in monologue and dialogue. In: London-Lund Corpus of Spoken English: Description and Research. Ed. J. Svartvik, Lund: Lund University Press, 1990, s. $211-252$.

SWERTS, Marc: 1998. Filled pauses as markers of discourse structure. In: Journal of pragmatics, 1998 , roč. 30, s. $485-496$.

VILLAR, Gina - ARCIULI, Joanne - MALLARD, David: Use of "um" in the deceptive speech of a convicted murderer. In: Applied Psycholinguistics, 2012, roč. 33, č. 1, s. 83 - 95. 